\title{
ON THE PROBLEM OF DETERMINING THE LEGAL STATUS OF CONVICTS SENTENCED TO IMPRISONMENT IN THE CRIMINAL AND EXECUTIVE LAW OF UKRAINE
}

\author{
Togochynskyi O. M., Chebonenko S. O.
}

\section{INTRODUCTION}

At the present the most important feature of Ukraine's development stage is the activity of all institutions of government and civil society, which is aimed at real changes in the functioning of society and the state. Reforming the penitentiary system of Ukraine is an integral part of the state policy of each state. An important direction of penitentiary policy is to ensure the rights and freedoms of man and citizen in relation to convicts and investigators.

According to Art. 1 of the Constitution of Ukraine, Ukraine is a sovereign and independent, democratic, social and legal state. A democratic state is one that is based on respect for human and civil rights and freedoms, their guarantee, as well as the control and accountability of public authorities. In Art. 1 of the Fundamental Law of our state Ukraine is characterized not only as a democratic, but also as a social and legal state. The main features of the legal state are: recognition, legislative consolidation and guarantee by the state of fundamental human and civil rights and freedoms; Rule of Law; division of power into legislative, executive and judicial; mutual responsibility of the person and the state; functioning of an independent and efficient judiciary; high level of legal consciousness and legal culture of both the individual and society as a whole. The vast majority of requirements that reveal the content of the rule of law are enshrined in the relevant sections and articles of the Constitution and create the necessary legal preconditions for its formation and development of Ukraine as a rule of law in which human rights are recognized as the highest social value ${ }^{1,2}$.

The mentioned provisions are directly enshrined in Art. 3 of the Constitution of Ukraine, according to which a person, his life and health, honor and dignity, inviolability and security are recognized in Ukraine as the highest social value. Human rights and freedoms and their guarantees determine the content and direction of the state. The state is accountable to man for his activities. The establishment and protection of human rights and freedoms is the main responsability of the state ${ }^{3}$.

\footnotetext{
1 Конституція України : Закон України від 28 червня 1996 року № 254к/96-ВР. Дата оновлення: 01.01.2020. URL : https://zakon.rada.gov.ua/laws/show/254к/96-вр\#Техt (дата звернення: 29.10.2020).

${ }^{2}$ Конституція України. Науково-практичний коментар / редкол.: В. Я. Тацій (голова редкол.), О.В. Петришин (відп. секретар), Ю.Г. Барабаш та ін. 2-ге вид., переробл. і допов. Харків: Право, 2011. С. 9-10.

3 Конституція України : Закон України від 28 червня 1996 року № 254к/96-ВР. Дата оновлення: 01.01.2020. URL : https://zakon.rada.gov.ua/laws/show/254к/96-вр\#Техt (дата звернення: 29.10.2020).
} 
This principle is fundamental for the formation and implementation of criminal enforcement policy of Ukraine. It is based on a system of measures aimed at humanizing the treatment of convicts in the form of imprisonment.

\section{General theoretical principles of determining the legal status of convicts sentenced to imprisonment in Ukraine}

We consider the position of Stepaniuk A.H. is correct, where he notes: "These norms are designed to incorporate the idea of humanism as philanthropy, charity, love of neighbor in the legal system, in the activities of bodies and institutions of execution of punishments. As a result of such incorporation, the understanding of the humanism of the execution of punishment as an executive activity, not deprived of human treatment of the convict, acquires a higher legal force, based on the authority of the law. Acting as a fundamental criterion for assessing the activities of law enforcement agencies, justice is central to ensuring human rights in the implementation of the inherent restrictions on punishment. Since the application of such restrictions significantly restricts the constitutional rights and legitimate interests of the convict, the fairness of the punishment, reflecting on the action and retribution for him, indicates the correspondence between the rights and obligations of citizens enshrined in the Constitution and limiting the legal status of convicts"4.

Along with domestic political, social, economic, criminological and other factors influencing the penitentiary system of Ukraine, it is necessary to highlight the foreign policy factor related to the process of Ukraine's integration into the political, legal and socio-economic space of the European Union, enshrined on the legislative level ${ }^{5}$.

At present, significant attention is paid to the reform of the penitentiary system of Ukraine, which is characterized by the humanization of the execution of criminal punishments in the form of imprisonment; respect for the human rights of convicts and prisoners; increasing the requirements for the training of personnel of bodies and institutions of execution of criminal punishments, including ones in the form of imprisonment.

One of the possible steps towards improving the efficiency of justice is the activity of state and local self-government bodies, public organizations and individual members of society to prevent crimes and rehabilitate convicts, as well as to improve the system of execution of punishments.

\footnotetext{
${ }^{4}$ Степанюк А Х. Актуальні проблеми виконання покарань (сутність та принципи кримінальновиконавчої діяльності: теоретико-правове дослідження): автореф. дис. ... докт. юрид. наук: 12.00 .08$. Харків, 2002. C. 18-19. URL : https://i-rc.org.ua/files/personalii/stepanuk-a-h.pdf (дата звернення: 29.10.2020).

5 Про загальнодержавну програму адаптації законодавства України до законодавства Європейського Союзу: Закон України від 18 березня 2004 року № 1629-IV. Дата оновлення: 04.11.2018. URL : https://zakon.rada.gov.ua/laws/show/1629-15\#Text (дата звернення: 01.10.2020).
} 
In order to implement the mentioned purposes the following should be done:

1) development and practical application of modern approaches to the management of penitentiary institutions. Addressing the overcrowding of penitentiary institutions, improving prison infrastructure and involving the private sector;

2) improvement of ethical and disciplinary rules and mechanisms of internal control in penitentiary institutions;

3) improvement of the system of serving a sentence by minors with ensuring their right to continue education and vocational training;

4) introduction of an individualized approach to serving a sentence, improvement of security measures in penitentiary institutions;

5) development of mechanisms to counteract and prevent ill-treatment in penitentiary institutions through external supervision and independent monitoring;

6) improvement of the legal framework for sentencing;

7) reduction of the number of punishments related to imprisonment;

8) development of regulatory and institutional framework for the provision of probation services;

9) retraining and training of penitentiary service personnel to create a fullfledged modern probation service; providing technical base for the functioning of the probation service ${ }^{6}$.

It is quite possible to agree with Krychun $\mathrm{Yu}$. A. that at the present the content of the legal status of citizens has significantly expanded and enriched. Previous human rights positions have been revised. The list of rights and freedoms of citizens has increased, and political and legal guarantees for ensuring the rights and freedoms not only of man and citizen, but also of those sentenced to imprisonment for a certain term have been strengthened ${ }^{7}$.

In confirmation of the mentioned above, we can cite the provisions of Part 2 of Art. 102 of the Criminal and Executive Code of Ukraine (hereinafter - CEC of Ukraine) according to which the regime in the colonies should minimize the difference between living conditions in the colony and freedom, which should increase the responsibility of convicts for their behavior and awareness of human dignity ${ }^{8}$.

In the modern scientific literature, theoretical and practical issues of execution of imprisonment for a certain period, the functioning of the system of penitentiary

\footnotetext{
${ }^{6}$ Стратегія реформування судоустрою, судочинства та суміжних правових інститутів на 2015-2020 роки: Указ Президента України від 20 травня 2015 року № 276/2015. URL : https://zakon.rada.gov.ua/laws/ show/276/2015\#Text (дата звернення: 06.09.2020).

${ }^{7}$ Кричун Ю.А. Теоретичні положення визначення поняття та змісту правового статусу засуджених до позбавлення волі. Держава та регіони. Серія: Право. 2014. № 2 (44). C. 83. URL : http://www.law.stateandregions.zp.ua/ archive/2_2014/16.pdf(дата звернення: 06.09.2020).

${ }^{8}$ Кримінально-виконавчий кодекс України: Закон України від 11 липня 2003 року № 1129-IV. Дата оновлення: 03.07.2020. URL : https://zakon.rada.gov.ua/laws/show/1129-15\#Tехt (дата звернення: 01.10.2020).
} 
institutions and ensuring correction and resocialization are covered in the works of Antonian Yu.M., Astemirova Z.A., Bodnar I.V., Burdin V.M., Dzhuzh O.M., Zabriyanskyi H.I., Kolb O.H., Maksymova N. Yu., Marchenko V.F., Merkulova V.O., Nalyvaiko V.S., Puzyriov M.S., Sakharov A.B., Severov O.P., Syniov V.M., Stepaniuk A.Kh., Struchkov M.O., Trubnikov V.M., Tuzov O.P., Fitsula M.M., Shmarova I.V., Yarmachenko V.M. and others.

On July 11, 2003, the CEC of Ukraine made changes to the conceptual and categorical apparatus of science of Ukrainian criminal and executive law. At the same time, the issue of determining the legal status of convicts remains one of the most controversial in the science of criminal and executive law of Ukraine, due to the complexity of the studied phenomena. This issue attracts the attention of a large number of scientists in the field of criminal and legal course and other fields of knowledge, which leads to numerous discussions and lack of unified opinion on the issue of determining the convicts legal status.

In the Correctional Labor Code of Ukraine on December 23, 1970 (hereinafter-CLC of Ukraine) the closest in meaning to the concept of "legal status" was its "Soviet" analogue - "legal position" (Article 8 of the CLC of Ukraine "Legal status of persons serving sentences in the form of imprisonment and correctional labor without imprisonment", Article 129 of the Criminal Procedure Code of Ukraine "Legal status of personnel")"

According to Art. 8 of the CLC of Ukraine, persons serving a sentence of imprisonment and correctional labor without imprisonment, have responsibilities and have their rights established by legislation for citizens of Ukraine, with restrictions provided for convicts, and also depend on the court verdict and regime established by this Code for serving a sentence of this type. The legal position of foreign citizens and stateless persons serving a sentence of imprisonment and correctional labor without imprisonment is determined by the legislation of Ukraine, which establishes the rights and obligations of these persons while staying in Ukraine, with the restrictions provided by law for convicts, as well as depending on the court verdict and the regime established by this Code for serving a sentence of this type. In Art. 129 of the CLC of Ukraine there was enshrined a rule on the legal status of personnel, according to which employees of penitentiary bodies and institutions, as well as members of their families are under state protection. The inviolability, honor and dignity of personnel are protected by law. Actions of officials and citizens that interfere the personnel responsabilities performance have liability under the law ${ }^{10}$.

\footnotetext{
${ }^{9}$ Виправно-трудовий кодекс України: Закон України від 23 грудня 1970 року № 3-4. Дата оновлення: 01.01.2004. URL : https://zakon.rada.gov.ua/laws/show/3325-07\#Tеxt (дата звернення: 06.09.2020).

10 Там само.
} 
From the mentioned provisions of the CLC of Ukraine follows that:

1) the Soviet correctional labor law was characterized by the use of the concept of "legal status", which in the text of the CLC of Ukraine occurs only three times, in particular, in Art. Art. 8 and 129;

2 ) the concept of "legal status of a convict", "legal status of personnel", "legal status of a person" or "legal status of a citizen" in the text of the mentioned "fundamental" correctional labor law of Ukraine was absent;

3) the concept of "legal position" was used by the Soviet legislator to characterize the rights and responsibilities of both convicts (Article 8 of the CLC of Ukraine) and personnel, that is employees of penal institutions (Article 129 of the CLC of Ukraine);

4) the content of the concept of "legal position" formally defined in the CLC of Ukraine consisted of the following elements:

- rights and responsibilities of convicts or personnel. Interestingly, the Soviet legislator in Art. 129 of the CLC of Ukraine establishes guarantees for the implementation of personnel rights, in particular, provides a general rule on the obligation to prosecute officials and citizens for obstructing the performance of their duties by personnel. Establishing a rule on guarantees for the implementation of the rights of personnel is an element of its legal position (status);

- preconditions for the existence of the legal category "legal position": sentenced to imprisonment of a citizen of Ukraine (Part 1 of Article 8 of the CLC of Ukraine), sentenced to imprisonment of a foreign citizen or stateless person (Part 2 of Article 8 of the CLC of Ukraine) the legal connection of the convict with a particular state or, conversely, certify the absence of such a connection; derived from the legal relationship between man and the state in legal science is generally considered as legal personality, thus legal capacity and capacity of the person, which is not mentioned in the text of the CLC of Ukraine;

- generally accepted type of legal regulation of criminal and executive relations - the initial provision, so to speak a "framework" of the content of the legal position of convicts sentenced to imprisonment according to which:

1) citizens of Ukraine serving sentences in the form of imprisonment, established by the legislation for citizens of Ukraine, with the restrictions provided by the legislation for convicts, and also depend on the court verdict and the regime established by CLC of Ukraine for serving sentences of this type;

2) the legal position of foreigners and stateless persons serving a sentence of imprisonment is determined by the legislation of Ukraine, which establishes the rights and obligations of these persons during their serving sentences in Ukraine, with restrictions provided by law for convicts, and also depend on the court verdict and the regime established by CLC of Ukraine for serving a sentence of this type ${ }^{11}$.

\footnotetext{
${ }^{11}$ Виправно-трудовий кодекс України: Закон України від 23 грудня 1970 року № 3-4. Дата оновлення: 01.01.2004. URL : https://zakon.rada.gov.ua/laws/show/3325-07\#Tехt (дата звернення: 06.09.2020).
} 
The narrowed perception of the legal position of convicts by the Soviet legislator can be explained by insufficient research of this category in the correctional labor law of the Soviet Union. The existence of the legal position (legal status) of an individual in general has long been denied. Representatives of civil law, in particular Bratus S.M. and Mitskevich O.V., identified legal status with the legal capacity of a person.

Patiulin V.A. in his study prooved the legal capacity to be only an element of the legal status of the person.

For adequate perception of the category "legal status of a convict sentenced to imprisonment" it is necessary to refer to the results of research in the theory of state and law, constitutional law of Ukraine, civil law, criminal procedural law, etc. Comprehensive application of various branches of law will contribute to the structuring and harmonization of the entire legal system and the system of legislation of Ukraine ${ }^{12}$.

According to Prof. Alekseev S.S., the legal status reflects the stable, static state of the subject of legal relations. It is a "common" tool in the implementation of legal norms. In real life, legal relations require a differentiated approach, so the phrase "legal provision" should be used when the rights and responsibilities of the subject develop as a result of its entry into specific legal relations ${ }^{13}$.

Human - is an intelligent being who has the will, the gift of thinking, is able to produce tools and can consciously use them. In human as an individual there are biological and social qualities. The natural basis of a man is characterized by the presence of a biological body, sense organs, physical strength and other biological characteristics. The social in man is characterized by a concentrated expression of those social relations that reflect his relationship with the outside world. The main connection of almost any person with the state is realized through his citizenship, which can be defined as a permanent political and legal connection of the individual with the state, which is reflected in their mutual rights and responsibilities ${ }^{14}$.

According to Art. 1 of the Law of Ukraine "On Citizenship" of January 18, 2001:

1) a citizen of Ukraine - is a person who has acquired the citizenship of Ukraine in the manner prescribed by the laws of Ukraine and international treaties of Ukraine;

2) foreigner - is a person who is not a citizen of Ukraine and is a citizen (subject) of another state or states;

\footnotetext{
12 Патюлин В.А. Государство и личность в СССР (правовые аспекты взаимоотношений). Москва : Наука, 1974. 246 с.

13 Алексеев С.С. Собрание сочинений в 10 т. Том 3. Проблемы теории права: Курс лекций. Москва : Статут, 2010. С. 252.

${ }^{14}$ Кельман М.С., Мурашин О.Г. Загальна теорія держави і права: підручник. Київ : Кондор, 2008. С. 47-48.
} 
3) stateless person - is a person whom no state considers in accordance with its legislation as its citizen ${ }^{15}$.

According to Art. Art. 2 and 3 "On the legal status of foreigners and stateless persons" of September 22, 2011 the legal status of foreigners and stateless persons is determined by the Constitution of Ukraine, this and other laws of Ukraine, as well as international treaties of Ukraine. If an international treaty of Ukraine establishes rules other than those provided for by this Law, the rules provided for by such international treaty of Ukraine shall apply. Foreigners and stateless persons legally staying in Ukraine have the same rights and freedoms and have the same obligations as citizens of Ukraine, except as provided by the Constitution, laws or international treaties of Ukraine. Foreigners and stateless persons who are under the jurisdiction of Ukraine, regardless of the legality of their stay, have the right to recognition of their legal personality and fundamental human rights and freedoms. Foreigners and stateless persons are obliged to strictly abide by the Constitution and laws of Ukraine, other normative legal acts, not to encroach on the rights and freedoms, honor and dignity of other people, the interests of society and the state ${ }^{16}$.

The state respects and protects the rights, freedoms and legitimate interests of convicts, provides the necessary conditions for their correction and resocialization, social and legal protection and their personal safety. Convicts enjoy all human and civil rights provided by the Constitution of Ukraine, except for the restrictions set by this Code, the laws of Ukraine and established by a court sentence (parts 1, 2 of Article 7 of the Criminal Procedure Code of Ukraine) ${ }^{17}$.

According to Part 3 and 4 of the Criminal Procedure Code of Ukraine, the legal status of convicted foreigners and stateless persons is determined by the laws of Ukraine, as well as international treaties of Ukraine. The legal status of convicts is determined by the laws of Ukraine, as well as by this Code, based on the procedure and conditions of execution and serving a specific type of punishment ${ }^{18}$.

Thus, convicted foreigners (foreign citizens or subjects) and stateless persons or persons with dual citizenship (bipatrids) serving sentences in the form of imprisonment in penal institutions of Ukraine, except as provided by the Constitution of Ukraine, laws or international treaties Ukraine, have the same rights and freedoms and also have the same responsibilities as citizens of Ukraine.

\footnotetext{
15 Про громадянство: Закон України від 18 січня 2001 року № 2235-III. (Дата оновлення: 25.08.2019). URL : https://zakon.rada.gov.ua/laws/show/2235-14\#Text (дата звернення: 13.11.2020).

16 Про правовий статус іноземців та осіб без громадянства: Закон України від 22 вересня 2011 року № 3773-IV. Дата оновлення: 18.07.2020. URL : https://zakon.rada.gov.ua/laws/show/3773-17\#Text (Дата звернення: 20.10.2020).

17 Кримінально-виконавчий кодекс України: Закон України від 11 липня 2003 року № 1129-IV. Дата оновлення: 03.07.2020. URL : https://zakon.rada.gov.ua/laws/show/1129-15\#Text (дата звернення: 01.10.2020).

18 Там само.
} 


\section{The problem of views pluralism on determining the legal status of convicts sentenced to imprisonment in Ukraine}

Nowadays, theoreticaly, legal status distinguishes between general, special (generic) and individual one. The general legal status includes the following constituent elements:

1) legal norms;

2) legal personality;

3) general subjective rights, freedoms and responsibilities;

4) legitimate interests;

5) citizenship;

6) legal liability;

7) legal principles;

8) legal relations of general status ${ }^{19}$.

However, Skakun O.F. notes that the legal status of a stateless person, foreign citizen or citizen, although are independent legal categories, but still they are all formed on the basis of the legal status of a citizen of a state, so it is appropriate to talk about a person`s legal status as a whole ${ }^{20}$.

Convicts sentenced to imprisonment primarily have the legal status of a person, so they are subject to international general and regional standards in the field of human rights protection: Universal Declaration of Human Rights, $1948^{21}$, International Covenant on Civil and Cultural Rights, $1966^{22}$, International Covenant on Economic, Social and Cultural Rights, $1966^{23}$, Convention for the Protection of Human Rights and Fundamental Freedoms $1995^{24}$, UN Standard Minimum Rules, 1955 and others.

The position of Vynohradova O.S. is also correct that: “... criminal and executive legislation is based on the fact that persons serving sentences have a general legal status of citizens. At the same time, along with the mechanism of the appearance of the convict's status, the legal status of citizens is limited. The usage certain general civil rights and freedoms by convicts is restricted. That is the

\footnotetext{
${ }^{19}$ Кельман М.С., Мурашин О.Г. Загальна теорія держави і права: підручник. Київ : Кондор, 2008. С. 47-48.

${ }^{20}$ Скакун О.Ф. Теорія держави і права: підручник / пер. з рос. Харків : Консум, 2008. С. 377.

21 Загальна декларація прав людини, прийнята і проголошена в резолюції 217 А (III) ГА ООН від 10 грудня 1948 року. URL : https://zakon.rada.gov.ua/laws/show/995_015\#Text (дата звернення: 05.11.2020).

${ }_{22}^{2}$ Міжнародний пакт про громадянські і культурні права 1966 р.: ратифіковано Указом Президії Верховної Ради Української РСР N 2148-VIII. (Дата оновлення: 19.10.1973). URL : https://zakon.rada.gov.ua/ laws/show/995_042\#Техt(дата звернення: 05.11.2020).

23 Міжнародний пакт про економічні, соціальні та культурні права 1966 р.: ратифіковано Указом Президії Верховної Ради Української РСР N 2148-VIII від 19.10.73 (Дата оновлення: 19.10.1973). URL : https://zakon.rada.gov.ua/laws/show/995_042\#Text (дата звернення: 05.11.2020).

24 Конвенція про захист прав людини і основоположних свобод 1995 р.: ратифікована Законом № 475/97-ВР від 17 липня1997 року. (Дата оновлення: 02.10.2012). URL : https://zakon.rada.gov.ua/laws/ show/995_004\#Техt (дата звернення: 05.11.2020).
} 
essence of punishment. In other words, punishment directly imposes certain restrictions on convicts sentenced to imprisonment in order to correct them and prevent from committing new crimes".

Special legal status - is a person`s status as a representative of a social group separated from a certain legally significant principle (type of activity, age, etc.), which is endowed in accordance with laws or other regulations with special and additional, rights and responsibilities, due to the peculiarities of the person's position and the needs of functional special activity (student, pensioner, serviceman, official, convict, prisoner, etc.); and which is also common to a certain group of people. The special status complements (the status of the deputy) or limits (the status of sentenced to imprisonment) the general legal status, that is corrects it. Unlike the general legal status, which is permanent, the special status has its transient character ${ }^{25}$.

The legal status of convicts serving a sentence of imprisonment is a kind of special status, which in turn is divided depending on the type of correctional facility into:

1) the legal status of convicts serving sentences in a correctional colony;

2) the legal status of convicts serving sentences in a minimum security colony with facilitated conditions of detention;

3 ) the legal status of convicts serving sentences in a minimum security colony with normal conditions of detention;

4) the legal status of convicts serving sentences in a medium security colony;

5) the legal status of convicts serving sentences in a maximum security colony.

Also, the legal status of convicts can be classified depending on the conviction of adulthood:

1) the legal status of an adult convict serving a sentence of imprisonment;

2) the legal status of a juvenile convict serving a sentence of imprisonment.

The legal status is divided according to the gender:

1) the legal status of a man serving a sentence of imprisonment;

2) the legal status of a woman serving a sentence of imprisonment.

At the same time, any classification of social phenomena is conditional, so the mentioned division of convicts depending on different criteria is also subject to expansion.

According to Chebotariova Yu. A., the legal status of convicts is a set of rights, legitimate interests and responsibilities fixed by the norms of various branches of law, which determine and characterize the status of a convict while serving his sentence ${ }^{26}$.

\footnotetext{
${ }^{25}$ Скакун О. Ф. Теорія держави і права: підручник. Пер. з рос. Харків : Консум, 2008.

26 Чеботарьова Ю. А. Правовий статус засуджених до позбавлення волі: автореф. дис. ... канд. юрид. наук: 12.00.08. Київ, 2005. С. 11.
} 
Some scientists suggest considering the legal status of convicts solely through the prism of rights and responsibilities. Thus, Minster M.V. in the dissertation "Legal status of women sentenced to imprisonment" uses the terms of "legal position" and "legal status" as synonyms, which means a set of personal, political, socio-economic rights, cultural rights and freedoms of convicted women, their special rights and responsibilities ${ }^{27}$.

Hel A.P. in his turn believes that "the legal status of convicts is understood as a set of their rights, legitimate interests and responsibilities based on the general status of citizens of Ukraine and enshrined in regulations of various branches of law, which depends on the type of criminal punishment and behavior during its period. That is, to the content of the legal status of convicts by certain elements traditionally include: a) subjective rights, b) legitimate interests, c) responsibilities of convicts",28.

Vynohradova S.O. holds the position which describes the legal status of persons sentenced to imprisonment as a set of subjective rights, legitimate interests and responsibilities enshrined in the rules of various branches of law, arising from the restriction, preservation, specification, addition of legal status of citizens of Ukraine, which depends on the set of measures of necessary behavior in the form of refraining from certain actions and performing certain actions, as well as changes depending on their behavior during the period of serving a criminal sentence in the form of imprisonment ${ }^{29}$.

Undoubtedly, each of the above mentioned definitions of the legal status of persons sentenced to imprisonment has a rational thought. However, none of them mentions a specific element that convicts acquire while serving their sentences these are special forms of implementation (consequences) of legal liability that can be applied only to persons serving a sentence of imprisonment (Art. 132 of the Criminal and Executive Code of Ukraine ${ }^{30}$, Art. 391-393 of the Criminal Code of Ukraine ${ }^{31}$ ). During the period of serving a sentence in the form of imprisonment convicts acquire special tort.

\footnotetext{
${ }^{27}$ Минстер М.В. Правовое положение женщин, осужденных к лишению свободы : автореф. дисс. ... канд. юрид. наук : 12.00.08. Иркутск, 2009. С. 7.

${ }^{28}$ Науково-практичний коментар Кримінально-виконавчого кодексу України / А.П. Гель, О.Г. Колб, В.О. Корчинський та ін.; за заг. ред. А.Х. Степанюка. Київ : Юрінком Інтер, 2008. С. 31.

${ }^{29}$ Виноградова С.О. Гуманізація системи виконання покарань в умовах Євроінтеграційних процесів : автореф. дис. ... канд. юрид. наук. Дніпро, 2019. С. 4.

${ }^{30}$ Кримінально-виконавчий кодекс України : Закон України від 11 липня 2003 року № 1129-IV. Дата оновлення: 03.07.2020. URL : https://zakon.rada.gov.ua/laws/show/1129-15\#Text (дата звернення: 01.10.2020).

${ }^{31}$ Кримінальний кодекс України: Закон України від 5 квітня 2001 року № 2341-ІІІ. Дата оновлення: 14.11.2020. URL : https://zakon.rada.gov.ua/laws/show/2341-14\#Tехt(дата звернення: 16.11.2020).
} 


\section{CONCLUSIONS}

The social feature in a man can be characterized by a concentrated expression of those social relations that reflect his relationship with the outside world. The main connection of almost any person with the state is realized through his citizenship, which can be defined as a permanent political and legal connection of the individual with the state, which is reflected in their mutual rights and responsibilities ${ }^{32}$.

Convicted foreigners (foreign citizens or subjects) and stateless persons or persons with dual citizenship (bipatrids) serving sentences in the form of imprisonment in penitentiary institutions of Ukraine use the same rights and freedoms and have the same responsibilities as citizens of Ukraine, except ones established by the Constitution of Ukraine, laws or international treaties of Ukraine.

The legal status of convicts serving a sentence of imprisonment is a kind of special status, which in turn is divided depending on:

1) the type of correctional facility;

2) the achievement of convict adulthood;

3 ) on the basis of gender.

The list of proposed criteria for classifying the legal status of convicts is not exhaustive and may be further expanded.

The legal status of convicts serving a sentence of imprisonment is based on the general legal status of a citizen of Ukraine and enshrined in international and national normative and legal acts, the state-guaranteed set of their subjective rights, legitimate interests and responsibilities, as well as a special tort, which depends on the type of correctional facility in which the convict is serving a sentence of imprisonment, his age and sex.

\section{SUMMARY}

The study is devoted to the problems of determining the legal status (position) of convicts serving sentences in the form of imprisonment in correctional colonies of Ukraine. The scientific work considers the legislative consolidation of the legal status of convicts sentenced to imprisonment in the Correctional Labor Code of Ukraine. The analysis of the definitions of the general and special legal status of the person in the state existing in legal science is carried out. The structural elements of the legal status of a convict sentenced to imprisonment are considered. Considering the analysis of the provisions of the current criminal and executive legislation of Ukraine, as well as the relevant doctrinal points of view, the author's definition of the concept of "legal status of a convict sentenced to imprisonment" was defined. The own definition of the concept

\footnotetext{
${ }^{32}$ Кельман М.С., Мурашин О.Г. Загальна теорія держави і права: підручник. Київ : Кондор, 2008. С. 47-48.
} 
"legal status of a convict sentenced to imprisonment" is proposed. The conclusion is made on the expediency of including legal responsibility as an element of the legal status of a convict sentenced to imprisonment.

\section{REFERENCES}

1. Алексеев С.С. Собрание сочинений в 10 т. Том 3. Проблемы теории права: Курс лекций. Москва : Статут, 2010. 781 с.

2. Братусь С.Н. Юридические лица в советском гражданском праве. Москва : Юриздат, 1947. 363 с.

3. Виноградова С.О. Гуманізація системи виконання покарань в умовах Євроінтеграційних процесів : дис. ... канд. юрид. наук. Дніпро, 2019. 202 с.

4. Виноградова С.О. Гуманізація системи виконання покарань в умовах Євроінтеграційних процесів : автореф. дис. ... канд. юрид. наук. Дніпро, 2019. $20 \mathrm{c}$.

5. Виправно-трудовий кодекс України : Закон України від 23 грудня 1970 року № 3-4. Дата оновлення: 01.01.2004. URL : https://zakon.rada.gov.ua/laws/ show/3325-07\#Text (дата звернення: 06.09.2020).

6. Загальна декларація прав людини, прийнята і проголошена в резолюції 217 А (III) Генеральної Асамблеї Організації Об'єднаних Націй від 10 грудня 1948 року. URL : https://zakon.rada.gov.ua/laws/show/995_015\#Text (дата звернення: 05.11.2020).

7. Кельман М.С., Мурашин О.Г. Загальна теорія держави і права: підручник. Київ : Кондор, 2008. 477 с.

8. Конвенція про захист прав людини і основоположних свобод 1995 р.: ратифікована Законом № 475/97-ВР від 17 липня 1997 року. (Дата оновлення: 02.10.2012). URL : https://zakon.rada.gov.ua/laws/show/ 995_004\#Text (дата звернення: 05.11.2020).

9. Конституція України. Науково-практичний коментар / редкол.: В.Я. Тацій (голова редкол.), О.В. Петришин (відп. секретар), Ю.Г. Барабаш та ін. 2-ге вид., переробл. і допов. Харків : Право, 2011. 1128 с.

10. Конституція України : Закон України від 28 червня 1996 року № 254к/96-BP. Дата оновлення: 01.01.2020. URL : https://zakon.rada.gov.ua/ laws/show/254к/96-вр\#Tехt (дата звернення: 29.10.2020).

11. Кримінальний кодекс України : Закон України від 5 квітня 2001 року № 2341-III. Дата оновлення: 14.11.2020. URL : https://zakon.rada.gov.ua/ laws/show/2341-14\#Tехt (дата звернення: 16.11.2020).

12. Кримінально-виконавчий кодекс України : Закон України від 11 липня 2003 року № 1129-IV. Дата оновлення: 03.07.2020. URL : https://zakon.rada. gov.ua/laws/show/1129-15\#Text (дата звернення: 01.10.2020). 
13. Кричун Ю.А. Теоретичні положення визначення поняття та змісту правового статусу засуджених до позбавлення волі. Держава та регіони. Серія: Право. 2014. № 2(44). С. 83-87. URL: http://www.law.stateandregions. zp.ua/archive/2_2014/16.pdf (дата звернення: 06.09.2020).

14. Минстер М.В. Правовое положение женщин, осужденных к лишению свободы : автореф. дисс. ... канд. юрид. Наук : 12.00.08. Иркутск, 2009. 22 с.

15. Мицкевич А.В. Субъекты советского права. Москва : Госюриздат, 1962. $213 \mathrm{c}$.

16. Міжнародний пакт про громадянські і культурні права 1966 р.: Міжнародний пакт ратифіковано Указом Президії Верховної Ради Української РСР № 2148-VIII. (Дата оновлення: 19.10.1973). URL : https://zakon.rada.gov.ua/laws/show/995_042\#Text (дата звернення: 05.11.2020).

17. Міжнародний пакт про економічні, соціальні та культурні права 1966 р.: ратифіковано Указом Президії Верховної Ради Української PCP № 2148-VIII від 19.10.73 (Дата оновлення: 19.10.1973). URL : https://zakon.rada.gov.ua/laws/show/995_042\#Text (дата звернення: 05.11.2020).

18. Науково-практичний коментар Кримінально-виконавчого кодексу України / А.П. Гель, О.Г. Колб, В.О. Корчинський та ін. ; за заг. ред. А.Х. Степанюка. Київ : Юрінком Інтер, 2008. 496 с.

19. Патюлин В. А. Государство и личность в СССР (правовые аспекты взаимоотношений). Москва : Наука, 1974. 246 с.

20. Про громадянство : Закон України від 18 січня 2001 року № 2235-III. (Дата оновлення: 25.08.2019). URL : https://zakon.rada.gov.ua/laws/show/ 2235-14\#Tеxt (дата звернення: 13.11.2020).

21. Про загальнодержавну програму адаптації законодавства України до законодавства Європейського Союзу : Закон України від 18 березня 2004 року № 1629-IV. Дата оновлення: 04.11.2018. URL : https://zakon.rada. gov.ua/laws/show/1629-15\#Text (дата звернення: 01.10.2020).

22. Про правовий статус іноземців та осіб без громадянства: Закон України від 22 вересня 2011 року № 3773-IV. Дата оновлення: 18.07.2020. URL : https://zakon.rada.gov.ua/laws/show/3773-17\#Text (дата звернення: 20.10.2020).

23. Скакун О.Ф. Теорія держави і права : підручник / пер. з рос. Харків : Консум, 2008. $656 \mathrm{c.}$

24. Степанюк А.Х. Актуальні проблеми виконання покарань (сутність та принципи кримінально-виконавчої діяльності: теоретико-правове дослідження) : автореф. дис. ... докт. юрид. Наук : 12.00.08. Харків, 2002. 33 с. 
URL : https://i-rc.org.ua/files/personalii/stepanuk-a-h.pdf (дата звернення: 29.10.2020).

25. Стратегія реформування судоустрою, судочинства та суміжних правових інститутів на 2015-2020 роки : Указ Президента України від 20 травня 2015 року № 276/2015. URL : https://zakon.rada.gov.ua/laws/show/ 276/2015\#Техt (дата звернення: 06.09.2020).

26. Чеботарьова Ю.А. Правовий статус засуджених до позбавлення волі : автореф. дис. ... канд. юрид. Наук : 12.00.08. Київ, 2005. 22 с.

\section{Information about authors:}

Togochynskyi O. M.,

Doctor of Sciences (Pedagogics), Professor, Colonel,

Rector

Academy of the State Penitentiary Service 34, Honcha str., Chernihiv, 14000, Ukraine

Chebonenko S. O.,

Candidate of Pedagogical Sciences, Associate Professor,

Vice-rector

Academy of the State Penitentiary Service 34, Honcha str., Chernihiv, 14000, Ukraine 